ORIGINAL ARTICLE

\title{
Determinants of Skilled Care Utilization among Pregnant Women Residents in an Urban Community in Kwara State, Northcentral Nigeria
}

\author{
A. Idowu ${ }^{1}$, Samuel A. Olowookere ${ }^{2^{*}}$,Olajide O. Abiola ${ }^{3}$, Adebowale F. \\ Akinwumi $^{4}$, Caleb Adegbenro ${ }^{2}$
}

OPEN ACCESS

Citation: A. Idowu, Samuel A. Olowookere,Olajide O. Abiola, Adebowale F. Akinwumi, Caleb Adegbenro. Determinants of Skilled Care Utilization by Pregnant Women Residents in an Urban Community in Kwara State, Northcentral Nigeria. J Health Sci 2017;27(3):291.

doi:http://dx.doi.org/10.4314/ejhs.v27i3.1

Received: January 6, 2017

Accepted January 10, 2017

Published: May 1, 2017

Copyright: () 2017 Idowu, A. et al. This is an open access article distributed under the terms of the Creative Commons Attribution License, which permits unrestricted use, distribution, and reproduction in any medium, provided the original author and source are credited. Funding: Nil

Competing Interests: The authors declare that this manuscript was approved by all authors in its form and that no competing interest exists.

Affiliation and Correspondence:

${ }^{1}$ Department of Community

Medicine, Bowen University

Teaching Hospital,P.O.Box 15,

Ogbomoso.Oyo State, Nigeria

${ }^{2}$ Department of Community Health,

Obafemi Awolowo University

Teaching Hospital, Ile-Ife, Osun

State, Nigeria

${ }^{3}$ Department of Surgery, Bowen

University Teaching

Hospital,P.O.Box 15, Ogbomoso,Oyo

State Nigeria

${ }^{4}$ Department of Community Health,

Obafemi Awolowo University, Ile-

Ife, Osun State, Nigeria

"Email: sanuolowookere@yahoo.com

\section{ABSTRACT}

BACKGROUND: Skilled attendant at delivery (SBA) is one of the key indicators used in assessing progress towards improved maternal health. This study aimed at identifying factors influencing SBA utilization in Ilorin, Nigeria.

METHODS: This cross-sectional study was carried out using multi-stage sampling technique among 400 participants in Ilorin, Northcentral Nigeria. A pre-tested questionnaire was used for data collection, and data analysis was done using descriptive and inferential statistics.

RESULTS: SBA supervised $73.8 \%$ births. Determinants of skilled birth attendance at delivery include higher education (AOR; 10.94, 95\% CI; 3.60-33.26), having only one child (AOR; 4.33, 95\% CI; 1.18-15.82), having at least 4 ANC attendance (AOR; 18.84, 95\% CI; 8.95-55.82) and residing near delivery sites (AOR; 11.49, 95\% CI; 2.43-55.56).

CONCLUSION: The proportion of births supervised by SBA needs improvement in Northcentral Nigeria. Full implementation of reproductive health policies will enhance skilled births in Nigeria. KEYWORDS: Skilled birth attendants, Antenatal care, utilization

\section{INTRODUCTION}

Skilled attendant at delivery is one of the key indicators used in assessing progress towards the Millennium Development Goal of improving maternal health (1).This is when a qualified health worker (such as a midwife, a nurse or a medical doctor) manages labour effectively, promptly identifies and manages complications and adequately supports with effective referral systems for specialised care when needed (2). The global target is for at least $90 \%$ of births to be supervised by Skilled Birth Attendants (SBA) worldwide by 2015 (3). However, for developing countries, the International Confederation of Mid-wives (ICM) and International Federation of Gynaecology and Obstetrics (FIGO) in 2002 proposed a target of one skilled birth attendant for every 5,000 populations. This means that a skilled attendant can be expected to attend 200 births every year (4). 
Empirical evidences have shown that early and regular attendance of antenatal care (ANC) by pregnant women and delivery under supervision of a skilled attendant are associated with improved reproductive health outcomes with resultant decrease in maternal and peri-natal deaths $(3,5)$. Studies have shown that SBA presence at delivery could prevent around $16 \%$ to $33 \%$ of maternal deaths $(6,7)$. In fact, countries where SBA are utilized at delivery have reduced maternal mortality rate to as low as 50 per 100,000 live births (8).

Sub-Saharan Africa (SSA) currently contributes to $57 \%$ of the 358,000 global maternal deaths (9). The life time risk of a woman dying during pregnancy, childbirth or in the early postnatal period is also very high in this sub-region; 1 in 31 compared to 1 in 4300 in developed regions (10). Regrettably, greater than one-third of the approximately 2.65 million stillbirths and 3.3 million neonatal deaths globally occur in SSA (11, 12).

Generally, the proportion of SBA supervised births in developing regions increased from 53\% in 1990 to 61\% in 2007; yet in South Asia and Sub Sahara Africa (SSA), this figure remained less than 50\% (13,14). Moreover, a substantial proportion of antenatal care users do not deliver with skilled attendants, and a significant proportion of mothers in developing countries still deliver at home unattended by SBA $(15,16)$. In Nigeria, the National Demographic and Health Survey 2013 (NDHS) reports an overall coverage of $38 \%$ for SBA at delivery, which partly explains the high maternal mortality ratio of 576 maternal deaths per 100,000 live births in the country (17). This grave scenario requires more researches to help in identifying factors that are associated with utilization of skilled care at births among pregnant women. This study has the potential of providing useful information for evidence-based decision making for policy makers working in the field of maternal and child health.

\section{METHODS}

Study site: This study was conducted in Ilorin West Local Government Area (LGA) of Ilorin,
Kwara State, Nigeria, between August and November, 2015. According to the 2006 population figure, about 364,666 people live there, making it the most densely populated Local Government Area in Kwara State.

The study design was descriptive crosssectional survey. Aminimum sample size of 369 was calculated using the Leslie-Kish formula for estimating single proportion (18). According to the 2013 NDHS, $38 \%$ of deliveries were supervised by skilled birth attendants (17) with the margin of error set at 5\%. The sample size was increased to 409 using a non-response rate of $10 \%$. All consenting women in the reproductive age group of 15-49 years with history of childbirths within 12 months preceding the survey were interviewed. Women who were too ill to give required information were exempted from the study.

The respondents were selected using multistage sampling technique. In the first stage, one ward was selected by balloting from the 12 electoral wards in Ilorin, West LGA. In the second stage, one enumeration area was selected by balloting from all the enumeration areas in the selected ward. In the third stage, all households in the selected enumeration area were recruited into the study. In the fourth stage, all eligible women were approached in the selected households to recruit them till the sample size was achieved.

Data collection method and instruments: Data were collected using semi-structured interviewerguided questionnaire based on findings from previous studies. The questionnaire was written in English language but translated into Yoruba, which is the major language spoken by the study population, and back translated into English language. The instrument was used to collect information on respondents' socio-demographic characteristics, antenatal and delivery care practices.

Data analysis: The data were field-edited daily and Statistical Package for Social Sciences (SPSS) version 21 (SPSS Inc, Chicago, IL, IBM Version) was used for analysis. Data were analysed using descriptive and inferential statistics. Bivariate chisquare test and multivariate logistic analyses were

DOI: http://dx.doi.org/10.4314/ejhs.v27i3.11 
performed on respondents' characteristics and factors that significantly predict availability of SBA at delivery. Adjusted odd ratio (AOR) and 95\% CI were presented and used as measures of the strength of association. A p value $<0.05$ was accepted as significant.

Respondents' socio-economic status: Using Oyedeji's classification of Social Class (19), respondents' socio-economic status was classified into three: low, middle and high. This classification used a composite score of respondents' educational levels and occupational types of their spouses; both were scored. The score ranged from 1 to 5 for respondents' educational level and spousal occupational types respectively. Respondents'scores from each of the occupational and educational categories were added together and rated out of 10 . Those who scored less than 5 points were grouped into lower social class; scores from 5 to 7 points were grouped into middle social class while those who scored between 8-10 points were grouped into high social class.

Ethical consideration: Approval to conduct the study was obtained from the Bowen University Ethical Review Committee and permission received from the Department of Primary Health Care, Ilorin, Central LGA. Written consent was obtained from study participants before they were allowed to participate in the study. Participation was entirely voluntary, and confidentiality was ensured. Study participants detected not to have used skilled birth attendants in the last delivery were adequately counselled against such practices in their subsequent deliveries.

\section{RESULTS}

A total of 400 copies of the questionnaire were considered satisfactorily completed by the respondents and were analysed out of the 420 that were administered (95\% response rate). The mean age (SD) of the respondents was $30.3 \pm 6.0$ years. Seventy-five percent of the respondents were married, while $58.3 \%$ had tertiary education. Most, $(66.7 \%)$, belonged to the middle socioeconomic class. The majority $(91.8 \%)$ had their first pregnancies when they were $\geq 20$ years of age, while $58.0 \%$ had two to four children (Table $1)$.

Table 1: Respondents' Socio-economic characteristics.

\begin{tabular}{|c|c|c|}
\hline $\begin{array}{l}\text { Socio-demographic } \\
\text { characteristics }\end{array}$ & $\begin{array}{l}\text { Number of } \\
\text { respondents } \\
\mathrm{N}=400\end{array}$ & Percent \\
\hline \multicolumn{3}{|l|}{ Age group (years) } \\
\hline$\leq 19$ & 14 & 3.5 \\
\hline $20-29$ & 174 & 43.5 \\
\hline $30-39$ & 168 & 42.0 \\
\hline $40-49$ & 44 & 11.0 \\
\hline Mean (SD) (years) & $30.3(6.4)$ & \\
\hline \multicolumn{3}{|l|}{ Marital status } \\
\hline Never married & 51 & 12.7 \\
\hline Married & 299 & 74.8 \\
\hline Separated & 20 & 5.0 \\
\hline Divorced & 19 & 4.8 \\
\hline Widowed & 11 & 2.7 \\
\hline \multicolumn{3}{|l|}{ Educational status } \\
\hline No formal education & 16 & 4.0 \\
\hline Primary education & 49 & 12.2 \\
\hline Secondary education & 102 & 25.5 \\
\hline Tertiary education & 233 & 58.3 \\
\hline \multicolumn{3}{|l|}{ Socio-economic status } \\
\hline Low & 37 & 9.2 \\
\hline Middle & 96 & 24.0 \\
\hline High & 267 & 66.8 \\
\hline \multicolumn{3}{|l|}{ Religion } \\
\hline Christianity & 176 & 44.0 \\
\hline Islam & 218 & 54.5 \\
\hline Traditional & 6 & 1.5 \\
\hline \multicolumn{3}{|l|}{ Age at first pregnancy } \\
\hline$\leq 19$ & 33 & 8.2 \\
\hline$\geq 20$ & 367 & 91.8 \\
\hline \multicolumn{3}{|l|}{ Number of children } \\
\hline 1 & 144 & 36.0 \\
\hline $2-4$ & 232 & 58.0 \\
\hline$\geq 5$ & 24 & 6.0 \\
\hline
\end{tabular}

The majority $(82.2 \%)$ of the respondents had at least one antenatal care visit in their last pregnancies. Most participants (62.9\%) had discussions on significant dangers signs in pregnancy, labour and puerperium during such visits. Over $77 \%$ commenced ANC visits at a

DOI: http://dx.doi.org/10.4314/ejhs.v27i3.11 
gestational age of more than three months. Decisions on where to go for ANC visits were taken by their spouses $(53.2 \%)$. Most women $(56.2 \%)$ had at least four ANC visits (Table 2).

Table 2: Respondents' antenatal care practice.

\begin{tabular}{|c|c|c|}
\hline Variables & Frequency & $\%$ \\
\hline \multicolumn{3}{|l|}{ Had ANC visits } \\
\hline Yes & 329 & 82.2 \\
\hline No & 71 & 17.8 \\
\hline Total & 400 & 100.0 \\
\hline \multicolumn{3}{|c|}{ Type of facility visited } \\
\hline Private Hospital & 146 & 44.4 \\
\hline Public Hospital & 167 & 50.8 \\
\hline Health post & 16 & 4.8 \\
\hline Total & 329 & 100.0 \\
\hline \multicolumn{3}{|c|}{$\begin{array}{l}\text { Age of the pregnancy at } \\
\text { first ANC visit }\end{array}$} \\
\hline$<3$ months & 74 & 22.5 \\
\hline$\geq 3$ months & 255 & 77.5 \\
\hline Total & 329 & 100.0 \\
\hline \multicolumn{3}{|c|}{ Frequency of ANC visits } \\
\hline Once & 26 & 7.9 \\
\hline Twice & 66 & 20.1 \\
\hline Thrice & 52 & 15.8 \\
\hline$\geq 4$ times & 185 & 56.2 \\
\hline Total & 329 & 100.0 \\
\hline \multicolumn{3}{|c|}{$\begin{array}{l}\text { Decision taker on where } \\
\text { to deliver }\end{array}$} \\
\hline Self & 90 & 27.4 \\
\hline Husband & 175 & 53.2 \\
\hline Relatives & 51 & 15.4 \\
\hline Others & 13 & 4.0 \\
\hline Total & 329 & 100.0 \\
\hline \multicolumn{3}{|c|}{$\begin{array}{l}\text { Had discussion on danger } \\
\text { signs }\end{array}$} \\
\hline Yes & 207 & 62.9 \\
\hline No & 122 & 37.1 \\
\hline Total & 329 & 100.0 \\
\hline
\end{tabular}

Table 3 shows that $76.8 \%$ of had hospital deliveries with $39.0 \%$ and $37.8 \%$ in private and public hospitals respectively. Meanwhile, 2.8\% delivered in Traditional Birth Attendant (TBA) homes while $15 \%$ of them had home deliveries. The major reason for hospital delivery was perceived better delivery services $(40.1 \%)$. Over two-fifth of those who delivered in hospitals lived close to those facilities i.e. within 10-30 minutes walking distance. Deliveries were supervised by nurses/midwives in $63.8 \%$ of them and by medical doctors in $32.2 \%$. Most $(96.1 \%)$ of our respondents who had hospital deliveries were satisfied with the services received.

Table 3: Respondents' delivery practice.

\begin{tabular}{|c|c|c|}
\hline Variables & Frequency & $\%$ \\
\hline \multicolumn{3}{|l|}{ Place of last delivery } \\
\hline Government Hospital & 151 & 37.7 \\
\hline Private Hospital & 156 & 39.0 \\
\hline Religious Homes & 23 & 5.8 \\
\hline Home deliveries & 59 & 14.7 \\
\hline Traditional Birth Attendant & 11 & 2.8 \\
\hline Total & 400 & 100.0 \\
\hline \multicolumn{3}{|l|}{ Reasons for Hospital } \\
\hline \multicolumn{3}{|l|}{ Delivery } \\
\hline Perceived better services & 123 & 40.1 \\
\hline $\begin{array}{l}\text { Close proximity to place of } \\
\text { residence }\end{array}$ & 47 & 15.3 \\
\hline Perceived better outcome & 98 & 31.9 \\
\hline $\begin{array}{l}\text { Fear of unfavourable } \\
\text { outcomes from home } \\
\text { delivery }\end{array}$ & 12 & 3.9 \\
\hline I was just told to deliver & 27 & 8.8 \\
\hline there & 307 & 100.0 \\
\hline Total & & \\
\hline \multicolumn{3}{|l|}{$\begin{array}{l}\text { Proximity of residents to the } \\
\text { health facility }\end{array}$} \\
\hline$<10$ minute walk & 72 & 23.5 \\
\hline 10-30 minute walk & 130 & 42.3 \\
\hline >30 minutes walk & 105 & 34.2 \\
\hline Total & 307 & 100.0 \\
\hline \multicolumn{3}{|l|}{$\begin{array}{l}\text { Type of Birth Attendants at } \\
\text { the health facility }\end{array}$} \\
\hline No attendants & 5 & 1.6 \\
\hline Doctor & 99 & 32.2 \\
\hline Nurse/ Midwife & 196 & 63.8 \\
\hline Health Assistant & 7 & 2.4 \\
\hline Total & 307 & 100.0 \\
\hline \multicolumn{3}{|l|}{$\begin{array}{l}\text { Level of satisfaction with } \\
\text { hospital delivery }\end{array}$} \\
\hline Satisfied & 295 & 96.1 \\
\hline Not satisfied & 12 & 3.9 \\
\hline Total & 307 & 100.0 \\
\hline
\end{tabular}

DOI: http://dx.doi.org/10.4314/ejhs.v27i3.11 
Table 4 shows that the proportion of women who delivered with SBA was significantly higher among women within the 30-39 age group, those with tertiary education, high socioeconomic status and whose age at first pregnancy was $\geq 20$ years $(\mathrm{p}=0.0001)$. Higher proportion of respondents who delivered with SBA belonged to those who had ANC visits, received ANC in private hospitals, and those living within 10-30 minutes walking distance to places of deliveries $(\mathrm{p}<0.05)$ (Table 5).

Table 4: Association between respondents' Socio-demographic characteristics and availability of skilled birth attendants.

\begin{tabular}{|c|c|c|c|c|}
\hline Variables & \multicolumn{2}{|c|}{$\begin{array}{l}\text { Skilled Birth Attendants present } \\
\text { at birth }\end{array}$} & $\chi^{2}$ & P-value \\
\hline \multicolumn{5}{|l|}{ Age Groups } \\
\hline$\leq 19$ & $1 \quad(7.0)$ & $13(93.0)$ & & \\
\hline $20-29$ & $128(73.6)$ & $46(26.4)$ & & \\
\hline $30-39$ & $134(80.0)$ & $34(20.0)$ & & \\
\hline $40-49$ & $32(73.0)$ & $12(27.0)$ & $31.521 * *$ & $0.0001 *$ \\
\hline \multicolumn{5}{|l|}{ Marital status } \\
\hline Never married & $33(64.7)$ & $18(35.3)$ & & \\
\hline Married & $231(77.0)$ & $68(23.0)$ & & \\
\hline Separated & $12(60.0)$ & $8(40.0)$ & & \\
\hline Divorced & $11(58.0)$ & $8(42.0)$ & & \\
\hline Widowed & $8(73.0)$ & $3(27.0)$ & $8.011 * *$ & 0.091 \\
\hline \multicolumn{5}{|l|}{ Educational status } \\
\hline No formal education & $2(2.5)$ & $14(87.5)$ & & \\
\hline Primary education & $26(53.0)$ & $23(47.0)$ & & \\
\hline Secondary education & $70(69.0)$ & $32(31.0)$ & & \\
\hline Tertiary education & $197(84.5)$ & $36(15.5)$ & $53.237 * *$ & $0.0001 *$ \\
\hline \multicolumn{5}{|l|}{ Socio-economic status } \\
\hline Low & $20(54.0)$ & $17(46.0)$ & & \\
\hline Middle & $57(59.0)$ & $39(41.0)$ & & \\
\hline High & $218(82.0)$ & $49(18.0)$ & $25.233 * *$ & $0.0001 *$ \\
\hline \multicolumn{5}{|l|}{ Religion } \\
\hline Christianity & $140(79.0)$ & $36(21.0)$ & & \\
\hline Islam & $151(69.0)$ & $67(31.0)$ & & \\
\hline Traditional & $3(50.0)$ & $3(50.0)$ & $6.930 * *$ & $0.0031 *$ \\
\hline \multicolumn{5}{|l|}{ Age at first pregnancy } \\
\hline$\leq 19$ & $12(36.0)$ & $21(64.0)$ & & \\
\hline$\geq 20$ & $283(77.0)$ & $84(23.0)$ & 25.968 & $0.0001 *$ \\
\hline \multicolumn{5}{|l|}{ Number of children } \\
\hline 1 & $108(94.0)$ & $8(6.0)$ & & \\
\hline $2-4$ & $173(99.0)$ & $2(1.0)$ & & \\
\hline$\geq 5$ & $14(92.0)$ & $2(8.0)$ & $9.190 * *$ & $0.010 *$ \\
\hline
\end{tabular}

*Significant at $\mathrm{p}<0.05 * *$ likelihood chi-square used 
Table 5: Association of respondents' obstetrics variables and availability of skilled birth attendants

\begin{tabular}{|c|c|c|c|c|}
\hline \multirow[t]{2}{*}{ Variables } & \multicolumn{2}{|c|}{ Skilled Birth Attendants present at birth } & \multirow[t]{2}{*}{$\mathrm{X}^{2}$} & \multirow[t]{2}{*}{ p-value } \\
\hline & $\begin{array}{l}\text { Yes }(\mathrm{N}=295) \\
\mathrm{n}(\%)\end{array}$ & $\begin{array}{l}\text { No }(\mathrm{N}=105) \\
\mathrm{n}(\%)\end{array}$ & & \\
\hline \multicolumn{5}{|l|}{ Had ANC } \\
\hline Yes & $287(97.0)$ & $10 \quad(3.0)$ & & \\
\hline No & $28(23.0)$ & $95(77.0)$ & 234.124 & $0.0001 *$ \\
\hline \multicolumn{5}{|l|}{ Type of facility visited } \\
\hline Health post & $15(23.0)$ & $50(77.0)$ & & \\
\hline Private Hospital & $124(83.0)$ & $25(17.0)$ & & \\
\hline Other Public Hospital & $156(84.0)$ & $30(16.0)$ & $102.96 * *$ & $0.001 *$ \\
\hline \multicolumn{5}{|c|}{ Gestational age at first ANC visits } \\
\hline$<3$ months & $67(43.0)$ & $87(57.0)$ & & \\
\hline$\geq 3$ months & $228(92.7)$ & $18(7.3)$ & 118.309 & $0.0001 *$ \\
\hline \multicolumn{5}{|l|}{ Frequency of ANC visits } \\
\hline 1-3times & $127(66.0)$ & $65(34.0)$ & & \\
\hline$\geq 4$ times & $168(80.8)$ & $40(19.2)$ & 51.067 & $0.0001 *$ \\
\hline \multicolumn{5}{|c|}{ Decision maker on where to deliver } \\
\hline Self & $84(77.0)$ & $25(23.0)$ & & \\
\hline Husband & $149(88.0)$ & $20(12.0)$ & & \\
\hline Relatives & $62(50.8)$ & $60(49.2)$ & $51.136 * *$ & $0.0001 *$ \\
\hline \multicolumn{5}{|c|}{ Had discussion on danger signs } \\
\hline Yes & $178(81.6)$ & $40(18.4)$ & & \\
\hline No & $117(64.0)$ & $65(36.0)$ & 15.451 & $0.0001 *$ \\
\hline \multicolumn{5}{|c|}{ Proximity of hospital to place of residence } \\
\hline$<10$ minutes & $67(68.0)$ & $32(32.0)$ & & \\
\hline 10-30 minutes & $126(88.0)$ & $17(12.0)$ & & \\
\hline$>30$ minutes & $102(65.0)$ & $56(35.0)$ & $13.757 * *$ & $0.001 *$ \\
\hline
\end{tabular}

*Significant at $\mathrm{p}<0.05 * *$ likelihood chi-square used

Table 6 shows that determinants of utilization of SBA include age $\leq 19$ years (AOR; $0.029,95 \% \mathrm{CI}$; $0.003-0.245$ ), tertiary education (AOR; 10.94, 95\% CI; 3.60-33.26), respondents with one child (AOR; 4.33, 95\% CI; 1.18-15.82), had $\geq 4$ ANC visits (AOR; 18.84, 95\% CI; 8.95-55.82) and those living near places of deliveries (AOR; 11.49, 95\% CI; 2.43-55.56).

\section{DISCUSSION}

This study assessed the factors associated with the use of skilled delivery care among women in Ilorin, Northcentral Nigeria. It reported that most women received ANC in their last pregnancies during which discussions on major danger signs in pregnancy, labour and puerperium were done. This agrees with the 2013 NDHS report for
Nigeria which shows that $67 \%$ of the women in Northgentral Nigeria received ANC from skilled personnel (17). However, studies elsewhere reported differing figures such as $31 \%$ in Nepal and $34 \%$ in Ethiopia $(20,21)$. Good ANC practice has been proven to correlate positively with availability of SBA at births $(22,23)$.

Husbands were the main decision makers with regard to where to receive ANC service in most respondents. Most communities in Nigeria practice patrimonial family system where most decisions are taken by men who are often the heads of the families. Families with supportive husbands in reproductive matters are more likely to utilize maternal health services compared to families where women take reproductive actions independent of their husbands (24-25).

DOI: http://dx.doi.org/10.4314/ejhs.v27i3.11 
Table 6: Logistic regression of respondent's variables and availability of skilled birth attendants at delivery.

\begin{tabular}{|c|c|c|c|}
\hline Variable & AOR & $95 \% \mathrm{CI}$ & $p$-value \\
\hline \multicolumn{4}{|c|}{ Age group (years) } \\
\hline$\leq 19$ & 0.029 & $0.003-0.245$ & $0.001 *$ \\
\hline $20-29$ & 1.043 & $0.496-2.196$ & 0.911 \\
\hline $30-39$ & 1.478 & $0.689-3.169$ & 0.315 \\
\hline 40-49 (ref & & & \\
\hline \multicolumn{4}{|c|}{ Education level } \\
\hline None (ref) & & & \\
\hline Primary & 2.487 & $0.751-8.230$ & 0.136 \\
\hline Secondary & 4.813 & $1.544-15.000$ & $0.007 *$ \\
\hline Tertiary & 10.944 & $3.601-33.262$ & $0.0001 *$ \\
\hline \multicolumn{4}{|c|}{$\begin{array}{l}\text { Age at first } \\
\text { pregnancy (years) }\end{array}$} \\
\hline $\begin{array}{l}<19 \\
\geq 20 \text { (ref) }\end{array}$ & 0.651 & $0.186-2.276$ & 0.502 \\
\hline \multicolumn{4}{|c|}{ Number of children } \\
\hline 1 & 4.337 & $1.189-15.817$ & $0.026^{*}$ \\
\hline $\begin{array}{l}2-4 \\
\geq 5 \text { (ref) }\end{array}$ & 2.204 & $0.728-6.668$ & 0.162 \\
\hline \multicolumn{4}{|l|}{ Had ANC } \\
\hline $\begin{array}{l}\text { Yes } \\
\text { No (ref) }\end{array}$ & 18.843 & $8.946-39.689$ & $0.0001 *$ \\
\hline \multicolumn{4}{|c|}{$\begin{array}{l}\text { Proximity of } \\
\text { hospital to place of } \\
\text { residence (minutes) }\end{array}$} \\
\hline$<10$ & 11.494 & $2.433-55.556$ & $0.002 *$ \\
\hline $\begin{array}{l}10-30 \\
>30 \text { (ref) }\end{array}$ & 1.149 & $0.222-5.962$ & 0.868 \\
\hline
\end{tabular}

$\mathrm{AOR}=$ adjusted odds ratio $\mathrm{CI}=$ confidence interval

*significant at $\mathrm{p}<0.05$

Almost three-quarter of the respondents in the current study had their deliveries supervised by SBA. According to the Nigerian NDHS report for $2013,46.5 \%$ of the women in the Northcentral geopolitical zone had SBA present during their deliveries, which was the fourth highest figure among the six geopolitical zones in Nigeria (17). The reason for the increased figure reported in the current study could have been due to socio-economic class and urban location of our respondents. These could have impacted positively on their knowledge-base subsequently creating a positive health-seeking behaviour with regard to delivery care utilization which is mostly present in the urban communities. In the current study, having SBA at births was significantly associated with age $\geq 20$ years and having higher education. Age and education status have been reported as important socio-demographic variables determining maternal healthcare services utilization $(26,27)$. Our finding could have been due to the fact that pregnant adolescents in developing countries tend to have inadequate knowledge about reproductive health matters and are usually in poor financial status. Hence, they are less likely to have access to high quality obstetric services provided by SBA.

This study reported that respondents who attended at least one ANC visit were more likely to have SBA at delivery. This could be because these respondents have received appropriate health information during their ANC visits regarding benefits of SBA utilization. Moreover, our study revealed that respondents who had one child had significantly increased odds of SBA uptake compared to those with five or more children. Besides, respondents whose homes were within walking distances from tend to deliver with SBA.These findings are in keeping with previous research $(20,24)$. Long distances could discourage SBA utilization among pregnant women particularly in developing countries with poor road networks and high level of insecurity.

Since the survey relied on information voluntarily provided by the respondents, the study may not be totally free from information bias as all the answers given may not be a true representation of actual utilization of SBA. Effort was made to minimize this bias by explaining in details how their response wound assist policy makers in designing cost-effective "safe delivery programmes" for pregnant women in Nigeria.

In conclusion, although most women in the Northcentral geopolitical zone of Nigeria utilized SBA as revealed by the current study; it is below the global target of $\geq 90 \%$ of deliveries being supervised by SBA. Thus, more efforts are required to ensure SBA at each delivery. In achieving this goal, stakeholders must guarantee enough health facilities offering Basic and Comprehensive obstetric care services to stem the tide of maternal deaths in Nigeria and other African countries thereby making the Sustainable Development Goals a reality.

\section{REFERENCES}

1. United Nations: The Millennium Development Goals Report 2005. New York: United Nations; 2006.

DOI: http://dx.doi.org/10.4314/ejhs.v27i3.11 
2. Filippi V, Ronsmans C, Campbell OMR, Graham WJ, Mills A, Borghi J, Koblinsky M, Osrin D. Maternal survival 5 - Maternal health in poor countries: the broader context and a call for action. Lancet 2006, 368(9546):1535-1541.

3. Official United Nations Documents for the Twentyfirst Special Session of the General Assembly New York, United Nations; 1999.

4. World Health Organization (WHO). Making pregnancy safer: the critical role of the skilled attendant. A joint statement by WHO, ICM and FIGO. WHO, Geneva Switzerland; 2004; 1 .

5. WHO, UNICEF, UNFPA. Maternal mortality in 2000: estimates developed by WHO, UNICEF and UNFPA. Geneva: UNFPA; 2004.

6. Scott S, Ronsmans C. The relationship between birth with a health professional and maternal mortality in observational studies: a review of the literature. Tropical Medicine and International Health 2009, 14(12):1523-1533.

7. WHO, UNICEF. Countdown to 2015 decade report (2000-2010) with country profiles taking stock of maternal, newborn and child survival. Geneva; New York: World Health Organization; UNICEF. 2010.

8. WHO UNICEF, The World Bank. Trends in maternal mortality 1990 to 2008: estimates. Geneva: World Health Organization. 2010

9. Lawn JE, Blencowe H, Pattinson R, Cousens S, Kumar R, et al. Stillbirths: Where? When? Why? How to make the data count? Lancet. 2011, 377: 1448-1463.

10. Oestergaard MZ, Inoue M, Yoshida S, Mahanani WR, Gore FM, et al. Neonatal mortality levels for 193 countries in 2009 with trends since 1990: a systematic analysis of progress, projections, and priorities. Plos medicine; 2008:8.

11. Graham WJ, Bell JS, Bullough CHW: Can skilled attendance at delivery reduce maternal mortality in developing countries? In Safe Motherhood Strategies: a Review of the Evidence. Edited by De missed opportunities. An analysis of trends, levels and differentials, 1990-2001. Geneva: WHO; 2003.

12. The Millennium Development Goals Report 2009New York, United Nations; 2009

13. Koblinsky MA, Campbell O, Heichelheim J. Review organizing delivery care: what works for safe motherhood? Bull World Health Organ. 1999; 77(5):399-406.

14. WHO/FIGO/International Confederation of Midwives. Definition of the midwife. The Hague: International Confederation of Midwives; 1992:4.
15. Uganda Bureau of Statistics (UBOS) and Macro International Inc: Uganda Demographic and Health Survey 2006. Calverton: UBOS and Macro International Inc; 2007.

16. National Population Census;ICF International. Nigerian Demographic and Health Survey. 2013

17. Harrison KH. The struggle to reduce high maternal mortality in Nigeria. Afr. J. Reprod. Health. 2009; 13(3):9-20.

18. Kish L. Survey Sampling. New York. John Wiley and Sons, Inc. 1965.

19. Oyedeji G. Socio-economic and cultural background of hospitalized children in Ilesha. Nigerian Medical Practitioner. 1985; 12: 111-117.

20. Dhakal S, Van TeijlingenE,Raja EA, Dhakal KB. Skilled care at birth among rural women in Nepal: practice and challenge. Journal of Health Population and Nutrition. 2011;29(4):371-378.

21. Hagos S, Debebe S, Meselech A, Alemayehu M, Mesganaw F, Afewirk A, Saifuddin A. Utilization of institution delivery service at Wukro and Butagera district in the Northern and Southern Central Ethiopia. BMC Pregnancy and Childbirth. 2014; $14: 178$

22. Islam N, Islam MT, Yoshimura Y. Practice and determinants of delivery by skilled birth attendants in Bangladesh. Reproductive Health.2014; 11:86

23. Jerome KK, Per-Olof O, Eleamor T, Karen OP. Knowledge of obstetrics danger signs and birth preparedness practices among women in rural Uganda. Reproductive Health. 2011;8: 33.

24. Onasoga AO, Osaji TA, Alade AO, Egbuniwe MC. Awareness and barriers to utilization of maternal health care service among reproductive women in Amassoma community, Bayelsa state. International Journal of nursing and midwifery. Available at htt://www.academic journal.org//IJNM. Accessed January $5^{\text {th }}, 2016$.

25. Ikeako LC, Onah HE, Iloabachie GC. Influence of formal maternal education on the use of maternity services in Enugu, Nigeria. Journal of Obstetrics and Gynaecology. 2006; 26 (1):30-4.

26. Wilunda C, Quoglio G, Putato G, Takahashi R, Calia F, Abebe D et al. Determinants of utilization of antenatal care and skilled birth attendant at delivery in Southwest Shoa Zone, Ethiopia: a cross-sectional study. Reproductive health. 2015; $12: 74$.

27. Brouwere V, van Lerberghe W. Antwerp, ITG Press; 2001:97-130. 